\title{
Telaah 'Childhood Place Attachment' sebagai Dasar Perubahan Ruang pada Kompleks Perumahan Modern (studi kasus pada Perumahan Chandra Kirana Regency Singosari)
}

\author{
Fenny Widiana1, Yusfan Adeputera Yusran² \\ ${ }^{1}$ Mahasiswa Program Magister Arsitektur Lingkungan Binaan Fakultas Teknik, Universitas Brawijaya \\ fenny.widiana@gmail.com \\ ${ }_{2}^{2}$ Pengajar pada Program Magister Arsitektur Lingkungan Binaan Fakultas Teknik, Universitas Brawijaya \\ yusfan@ub.ac.id
}

\begin{abstract}
ABSTRAK
Perubahan pada unit rumah tinggal pada suatu kompleks perumahan sekarang marak terjadi. Ditemukan banyak rumah yang sudah tidak sesuai dengan bentuk rumah asli yang direncanakan oleh pengembang (developer) kompleks perumahan. Hal ini memperlihatkan bahwa terdapat ketidakpuasan penghuni terhadap rancangan rumah yang disediakan sehingga penghuni memilih untuk melakukan perubahan khususnya pada ruang. Kajian ini bertujuan untuk mengidentifikasi dan menganalisis keterikatan tempat saat masa kecil dan kearifan lokal yang mempengaruhi perubahan ruang pada sebuah kompleks perumahan dengan mengambil kasus di Perumahan Chandra Kirana Regency Singosari Kabupaten Malang. Kajian ini menggunakan metode kualitatif dengan pendekatan fenomenologi melalui in-depth interview dan survey lapangan pada purposive sampel, kemudian hasilnya dianalisis dengan dua unsur utama kearifan lokal, yaitu manusia beserta pola pikirnya dan alam beserta lingkungannya. Dari hasil kajian ditemukan bahwa terdapat keterikatan antara kenangan masa kecil dengan bentuk rumah masa kini yang terlihat dari susunan penataan ruang dalam rumah saat ini. Selain itu, nilai budaya setempat atau kearifan local juga berpengaruh dalam perubahan tersebut.
\end{abstract}

Kata kunci: childhood place attachment, kearifan lokal, perubahan ruang, metode fenomenologi

\begin{abstract}
Changes in residential units are common happen in a housing complex. Found many houses that are not in accordance with the original house form which planned by the developer in a new housing complex in the district of Malang. It shows that dissatisfaction of residents to the house's design makes them add some changes, especially in the space. This study aims to identify and analyze the attachment of places during childhood and local wisdom that affects the change of space in a housing complex by taking the case in the Chandra Kirana Regency Singosari, Malang. This study uses the qualitative method with phenomenology approach through indepth interview and field survey on purposive samples, then the result is analyzed with two main elements of local wisdom, that is the man and its nature. From the results of the study found that there is an attachment between childhood memories with the present form of the houses seen from the composition of spatial arrangement in the house. In addition, local wisdom also influences the change.
\end{abstract}

Keywords: childhood place attachment, local wisdom, change of plan, phenomenological method 


\section{Pendahuluan}

Pembangunan perumahan pada saat ini mengalami peningkatan yang pesat. Hal ini dapat dilihat dari semakin banyaknya kompleks perumahan baru di perkotaan, seperti Kota Malang sebagai kota terbesar kedua di Jawa Timur setelah Surabaya. Namun keterbatasan lahan dan peningkatan harga tanah di Kota Malang, memaksa pengembangan permukiman mengarah ke wilayah pinggiran Kota Malang yaitu Kabupaten Malang. Menurut Rencana Tata Ruang Wilayah Kabupaten Malang, terdapat beberapa kecamatan di sekeliling Kota Malang yang berfungsi sebagai Wilayah Pengembangan Lingkar Kota Malang, yaitu kecamatan Lawang, kecamatan Singosari, kecamatan Karangploso, kecamatan Dau, Kecamata Pakisaji, kecamatan Wagir, kecamatan Tajinan, kecamatan Bululawang, dan kecamatan Pakis. Dari hasil pengamatan, kecamatan Singosari memiliki potensi pengembangan yang lebih besar karena selain sebagai wilayah pengembangan juga sebagai wilayah penghubung dua kota besar di Jawa Timur, yaitu Surabaya dan Malang. Perumahan pada wilayah ini menjadi pilihan bagi karyawan yang bekerja di daerah Pandaan, Surabaya dan sekitarnya, tetapi ingin memiliki hunian dengan lingkungan yang masih asri. Salah satu perumahan pada wilayah ini yang mengalami perkembangan pesat di wilayah Singosari adalah perumahan Chandra Kirana Regency karena letaknya tidak jauh dari jalan penghubung dua kota besar di jawa Timur sehingga memiliki akses yang baik dengan lingkungan yang masih asri. Hal ini yang mendasari pemilihan perumahan Chandra Kirana Regency sebagai objek penelitian.

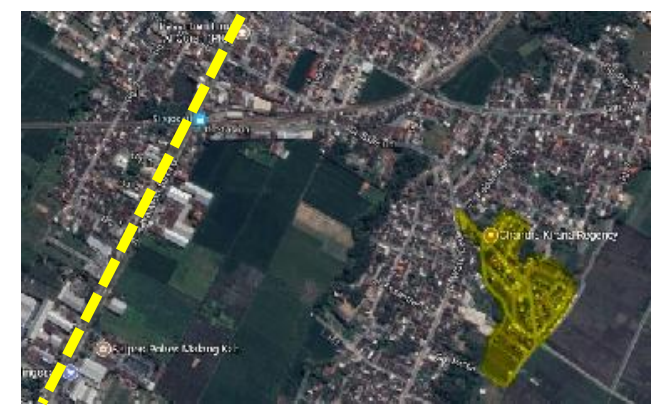

Gambar 1. Lokasi penelitian perumahan Chandra Kirana Regency dan posisinya terhadap jalur utama provinsi

Sumber : Diolah dari google/maps

Secara faktual banyak terjadi perubahan fisik pada unit rumah di kompleks perumahan. Hal ini menandakan ketidaksesuaian penghuni terhadap rumah yang disediakan pihak pengembang (Stevanus, 2015). Perbedaan bentuk rumah (tempat tinggal) merupakan suatu fenomena sebagai respon masyarakat terhadap suatu lingkungan fisik (Rapoport, 1969).

Menurut Chawla dalam Altman (1992), untuk mengukur keterikatan anak-anak terhadap suatu tempat adalah apabila mereka menunjukkan kebahagiaan ketika berada di dalamnya, sedih ketika meninggalkannya dan ketika nilai tersebut tidak hanya untuk kepuasan tetapi lebih kepada keterikatan yang mendalam. Tempat-tempat inilah yang turut membentuk kualitas hidup seseorang saat dewasa. Seorang anak memiliki keterkaitan dengan rumah, yang diasosiasikan dengan anggota keluarga yang dicintai. Pada usia pra-sekolah, pengalaman tempat anak-anak adalah hubungan sosial primer dengan pengasuh yang terbatas pada lingkungan dalam dan sekitar rumah. Namun pada masa remaja terjadi ambigu status sosial antara menjadi bagian dari keluarga atau menjadi seorang dewasa yang mandiri, pada sebuah divisi geografis antara rumah dan 
tempat komunitas yang lebih jauh. Pada masa inilah kekuatan fisik dan kecerdasan menampilkan reputasi sosial dan identitas diri yang memunculkan nilai lingkungan setempat. Identitas yang terbentuk di tempat lain sebelumnya mempengaruhi tempat yang tidak hanya sebagai hunian tetapi juga sebuah konsekuensi dari pengalaman manusia menghuni bangunan rumah.

Terdapat tiga aspek kepuasan sebuah tempat (Altman, 1992), yaitu (1) keamanan, (2) afiliasi sosial, (3) ekpresi kreatif dan ekplorasi. Sedangkan menurut Asikin dan Ridwan (2007), identitas harkat dan martabat manusia dalam komunitasnya merupakan entitas yang ditentukan oleh kearifan lokal. Kearifan lokal merupakan pengetahuan lokal berdasarkan pada nilai-nilai budaya lokal yang dapat dirasakan melalui kehidupan sehari-hari masyarakat serta merupakan respon/hasil proses dialektika antara individu dan lingkungannya. Kearifan lokal dianggap sebagai pandangan hidup dan ilmu pengetahuan serta berbagai strategi kehidupan yang berwujud aktifitas yang dilakukan masyarakat lokal dalam menjawab masalah dalam pemenuhan kebutuhannya. Kearifan lokal pada individu muncul sebagai hasil dari proses kerja kognitif individu sebagai upaya menetapkan pilihan nilai-nilai yang dianggap paling tepat bagi masing-masing individu. Sedangkan pada sebuah kelompok, kearifan lokal merupakan upaya menemukan nilai-nilai bersama sebagai akibat dari pola-pola hubungan yang telah tersusun dalam sebuah lingkungan, baik lingkungan fisik maupun non fisik. Kearifan lokal memiliki dua unsur utama, yaitu manusia beserta pola pikirnya dan alam beserta lingkungannya (Soedigdo, 2014; Dahlia, 2015 dalam Asikin, 2017). Kajian ini bertujuan untuk mengidentifikasi dan menganalisa keterikatan tempat pada masa kecil dan kearifan lokal yang mempengaruhi perubahan ruang pada perumahan. Variable yang digunakan adalah pada ruang personal dan teritorialitas manusia, serta tata ruang dan penggunaan ruang dalam unit bangunan.

\section{Metode}

Metode kajian yang digunakan adalah metode kualitatif dengan pendekatan fenomenologi yang bertujuan untuk mencari pemahaman dari pengalaman berdasarkan memory, citra dan makna dari sudut pandang orang-orang yang mengalaminya (Groat dan Wang, 2013). Fenomenologi sebagai lived experienced yaitu mengalami dan memahami arsitektur yang kemudian dideskripsikan secara langsung. Deskripsi yang dilakukan merupakan tahap awal untuk memahami makna dan intisari dari fenomena arsitektur, sebagai sebuah proses self-realization atau proses interaksi terus menerus terhadap kehidupan suatu tempat (Schulz dan Klassen dalam Gunawan, 2012).

Kajian ini dilakukan untuk memahami perubahan bentuk denah pada perumahan Chandra Kirana Regency yang didasari pada keterkaitan sebuah tempat pada masa anakanak, yakni keterkaitan dengan rumah masa kecil penghuni. Metode pengambilan data dengan cara in-depth interview pada narasumber penghuni perumahan, serta pengamatan dan penggambaran denah oleh narasumber.

Fokus penelitian pada perubahan bentuk kemudian dianalisis berdasarkan unsur kearifan lokal, yaitu manusia beserta pola pikirnya (ruang personal dan teritorialitas) dan alam beserta lingkungannya (tata ruang dan penggunaannya). Kajian dilakukan pada skala mikro atau hunian dari beberapa sample. Pemilihan sample dengan cara purposive sampling. Setiap tipe hunian pada perumahan diwakili beberapa rumah yang mengalami perubahan dari yang direncanakan oleh pengembang. Lokasi sample penelitian ditunjukkan pada gambar di bawah ini. 

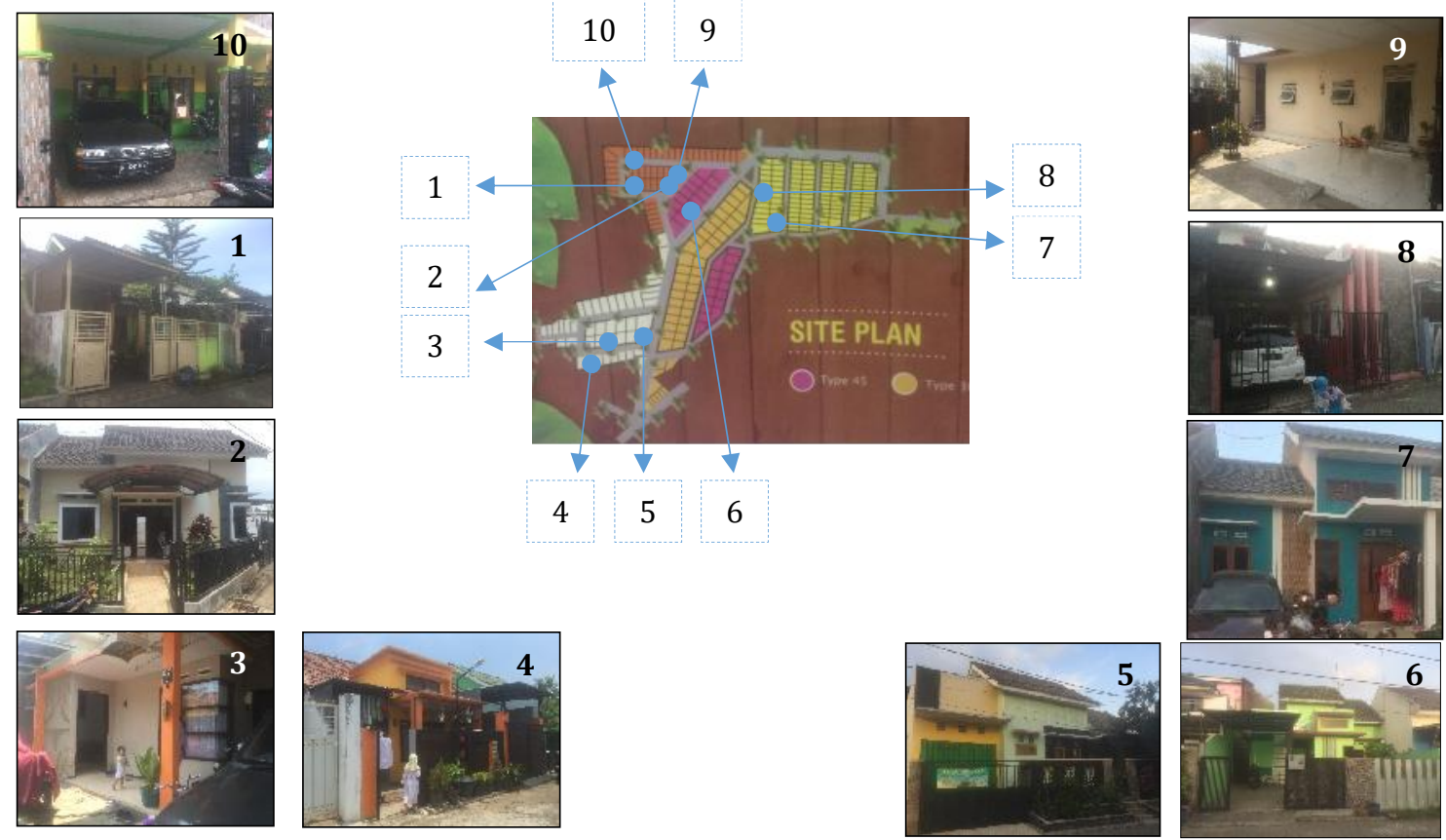

Gambar 2. Lokasi penelitian beserta objek studinya

\section{Hasil dan Diskusi}

Setiap manusia dewasa pasti berangkat dari masa anak-anak, yang dapat digambarkan sebagai pondasi sebuah bangunan. Sigmund Frued (dalam Yolanda, 2012) mengatakan bahwa masa kecil adalah masa yang paling rentan, karena pada masa ini kepribadian dan karakter seseorang terbentuk. Masa anak-anak merupakan masa ketika manusia mengalami pembelajaran dimana mereka akan menerima dan merespon kejadian yang ada disekitarnya sehingga masa ini merupakan periode penting dalam pengembangan kepribadian selanjutnya. Pembentukan sikap hidup kita saat ini atau yang masa mendatang merupakan impresi dari masa anak-anak, dimana mereka belajar dari lingkungan sekitarnya (Yolanda, 2012). Menurut Chawla (1992) studi mengenai tempat pada masa anak-anak sangat penting karena berkontribusi pada kualitas hidup seseorang pada masa sekarang.

Kearifan lokal merupakan unsur tradisi budaya yang menyelaraskan kehidupan manusia dengan cara menghargai, memelihara dan melestarikan lingkungan alam. Kearifan lokal, dalam arsitektur, merupakan langkah penerapan dari tradisi yang diterjemahkan dalam tatanan fisik bangunan maupun kawasan (Asikin, 2017). Terdapat dua unsur utama dalam kearifan lokal, yaitu manusia beserta pola pikirnya dan alam beserta lingkungannya dan dapat dilihat melalui karakter lingkungan fisik dan non fisik. Lingkungan fisik mencakup lingkungan alam, lingkungan binaan, permukiman, kawasan dan unit-unit bangunan yang dalam skala mikro dapat dilihat dari tata ruang dalam bangunan. Sedangkan lingkungan non fisik meliputi aspek sosial budaya masyarakat (Asikin, 2017).

Sinai dalam Stevanus (2015) menyebutkan bahwa ada beberapa cara penyesuaian diri penghuni rumah terhadap tempat tinggalnya, antara lain dengan mengadapatasi norma keluarga, adaptasi struktur keluarga, mobilitas tempat tinggal dan yang terakhir adalah merubah tempat tinggalnya agar lebih mampu mewadahi kebutuhan keluarga yang dirasa kurang. Berdasarkan unsur kearifan lokal dan cara beradaptasi manusia terhadap tempat tinggalnya, kajian ini difokuskan pada tata ruang hunian. 
Pada perumahan Chandra Kirana Regency para penghuni merubah tata ruang awal sesuai dengan kebutuhannya. Dalam analisis perubahan ini digolongkan menjadi dua kategori, yaitu penggunaan dan letak ruang. Untuk memudahkan, hasil analisi disajikan dalam bentuk tabel sebagai berikut.

\section{Tabel 1. Perubahan Tata Ruang dari rumah masa anak-anak dengan rumah di masa kini}

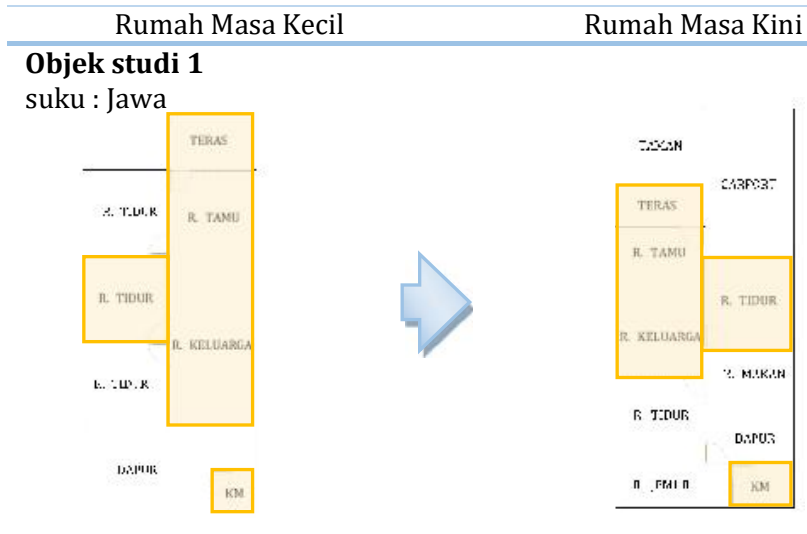

Objek studi 2

suku : Jawa

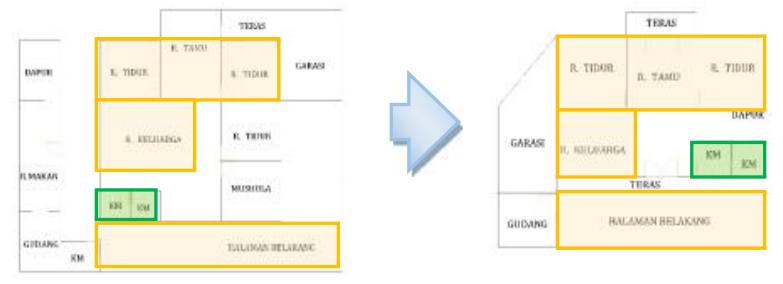

Keterkaitannya menurut penghuni

Objek studi 3 suku : Jawa

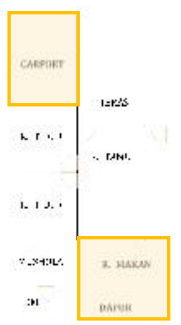

Tidak terdapat keterkaitan, namun terdapat 4 jenis ruang yang memiliki letak yang sama dan satu ruang terletak berlawanan.

\section{Objek studi 4}

suku : Jawa

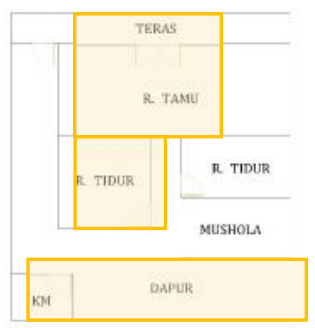

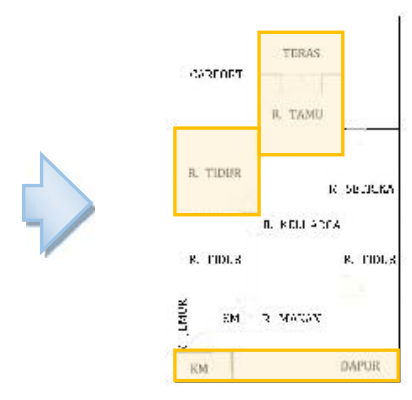

Tidak terdapat keterkaitan,

Tetapi sebagian besar ruangannya memiliki letak yang sama. Jumlah yang sama serta letak kamar mandi yang bersebelahan.
Tidak terdapat keterkaitan ,

Namun untuk dapur dan ruang makan berada pada posisi yang sama.

Sedangkan penambahan fungsi ruang kerja karena perbedaan profesi dengan orang tua. 
Objek studi 5

suku : Jawa

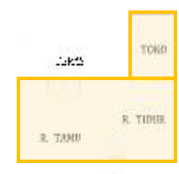

k 116v:

เ. K.

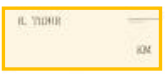

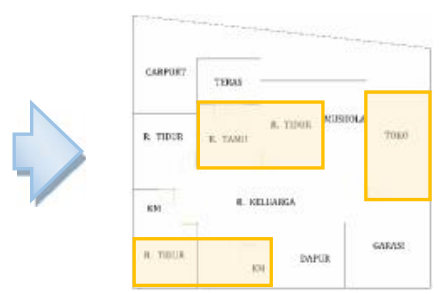

Terdapat keterikatan, karena kesamaan profesi, dan meletakkan ruang toko pada sisi yang sama, begitu pula dengan ruang tamu dan ruang tidur yang bersebelahan dan ruang tidur berdekatan dengan kamar mandi pada bagian dalam hunian.

Objek studi 6

suku : Jawa

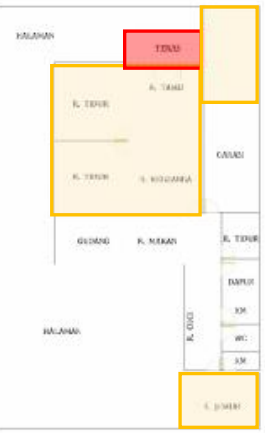

Objek studi 7

suku : Jawa
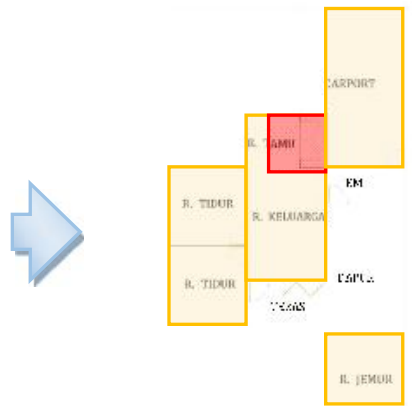

Terdapat keterikatan.

Penghuni memilih arah hadap rumah yang berbeda karena pada rumah terdahulu bagian depan rumah terdiri dari kaca, sehingga aktivitas di dalam rumah dapat terlihat dari jalan.

Namun, selain itu beberapa ruang memiliki letak yang sama, atau pada sisi yang sama
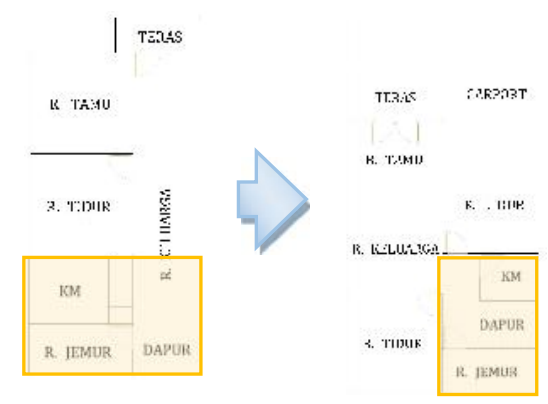

Tidak terdapat keterkaitan, namun untuk area servis dapur, kamar mandi dan ruang jemur berada pada lokasi yang sama yaitu di bagian dalam hunian.

\section{Objek studi 8}

suku : Jawa

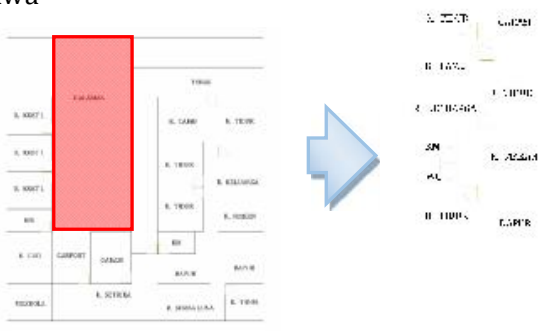

Terdapat keterikatan.

Penghuni tidak menerapkan pola ruang rumah masa kecilnya karena memiliki kenangan buruk ketika membersiihkan halaman rumah yang besar, sehingga semua lahan dibangun dengan pemanfaatanya sebagai kamar. 
Objek studi 9

suku : Jawa

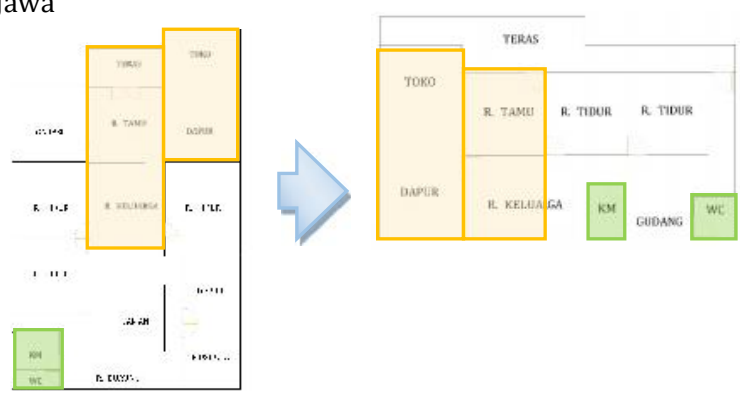

Terdapat keterkaitan dengan rumah masa kecil dimana letak dapur berada di belakang toko agar mudah untuk melayani pembeli, sedangkan letak ruang tamu dan ruang keluarga berada di samping toko dan dapur. Jumlah kamar mandi juga memililki kesamaan namun dengan letak yang berbeda.

Objek studi 10 suku : Jawa

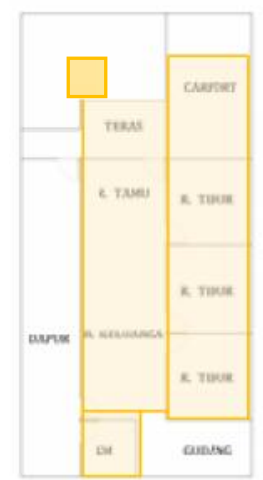

Keterangan :

(Sumber: Hasil analisa, 2017)

Dari hasil wawancara dan survey lapangan didapatkan bahwa terdapat keterikatan bentuk denah rumah masa kini dengan denah rumah pada masa anak-anak baik secara sadar maupun tidak sadar. Hal ini terlihat dari enam sampel yang mengatakan adanya pengaruh rumah masa kecil dengan rumah masa kini. Dan empat dari sampel mengatakan tidak adanya pengaruh denah rumah masa kecil dengan masa kini namun pada susunan ruangnya terdapat beberapa kesamaan. Kesamaan antara rumah masa kecil dengan rumah sekarang adalah letak ruang, fungsi yang berdekatan dan jumlah ruang. Beberapa contohnya adalah letak ruang tamu terhadap kamar tidur pada bagian depan, letak ruang tamu terhadap ruang keluarga yang tidak memiliki sekat dan letak dapur serta kamar mandi yang berada di belakang, juga jumlah kamar mandi dan kamar tidur.

Mukhlis (2016) menjelaskan bahwa anak-anak memiliki beberapa jenis tempat spesial untuk memenuhi beberapa tujuan dalam hidup, hal ini terlihat juga pada pemilihan fungsi ruang pada masa dewasa. Pada beberapa rumah terdapat ruang yang digunakan sebagai sumber matapencaharian seperti toko. Mereka yang mempunyai toko pada rumah masa kini adalah mereka yang mempunyai toko pula di rumah masa kecilnya. Pemilihan letak ruang toko juga berpengaruh, pada sampel no 5 lokasi perletakan toko pada bagian depan sebelah kanan memiliki kesamaan dengan rumah di masa kecilnya. Sedangkan untuk sampel no 9, perletakan ruang toko pada rumah kini sama persis dengan rumah masa anak-anak dimana toko berdekatan dengan dapur, dimaksudkan untuk dapat menjaga toko walaupun dengan melakukan kegiatan di dapur. Pada sampel no 8 menunjukkan keberlawanan antara rumah masa kecil dengan rumah sekarang. Penghuni menghindari keberadaan halaman yang luas seperti pada rumah masa kecilnya dengan membangun seluruh lahannya sehingga tidak memiliki halaman 
karena adanya pengalaman tidak menyenangkan yang membekas, yaitu pekerjaan menyapu halaman luas yang tidak disenangi. Hal ini menegaskan pernyataan Hummon dan Low dalam Muchlis (2016) bahwa keterikatan terhadap suatu tempat adalah ikatan kognisi dan emosional yang melibatkan tempat baik bersifat positif maupun negatif.

Keterikatan sebuah tempat dengan masa anak-anak dapat dikelompokkan menjadi tiga, yaitu kelompok yang tidak merasa adanya keterikatan tetapi pola ruangnya memiliki kesamaan dengan rumah dimasa kecil, kelompok yang memiliki keterikatan dengan pengalaman positif dan mengimplementasikan pada pola ruang huniannya pada masa sekarang; sedangkan kelompok terakhir adalah kelompok yang memiliki keterikatan dengan pengalaman negatif sehingga pola ruang huniannya tidak memiliki kesamaan dengan pola ruang rumah masa kecilnya. Hal ini sesuai dengan konsep tentang pembentukan seorang anak yang begitu terpengaruh oleh keadaan lingkungan sekitarnya yang pada masa ini adalah keluarga sebagai lingkup sosial terkecil dalam kehidupan seorang anak. Sedangkan aspek lingkungan yang turut mempengaruhi adalah kebudayaan Jawa, karena dari seluruh sample merupakan masyarakat Jawa. Hal ini menunjukan bahwa konteks budaya sangat berpengaruh terhadap perilaku manusia termasuk dalam proses memilih tempat spesial, dalam hal ini adalah rumah (Mukhlis, 2016). Proses personal, sosial dan budaya memaknai ikatan manusia dengan tempatnya (Asikin, 2017).

Ruang personal pada unit perumahan ini dibentuk dengan cara pembentukan pagar sebagai batas terluar hunian. Hal ini menunjukkan bordering process (Smith dalam Asikin, 2017) sebagai upaya untuk mengontrol akses yang dikuasainya dengan menciptakan ruang yang terbatasi dan wilayah teritorialitas penghuni. Seperti anak-anak yang menggunakan ruang favorit sebagai daerah otonomi mereka dimana tidak semua orang dapat memasukinya. Pembatasan ruang ini turut mengembangkan rasa otonomi sekaligus mengembangkan identitas kepribadian anak-anak (Ericson dalam Mukhlis, 2016). Ruang personal dan teritorialitas pada rumah diwujudkan melalui komposisi ruang dari area publik dan privat, yaitu dimulai dari teras depan, ruang tamu, ruang tidur, ruang keluarga, kemudian dapur dan ruang penyimpanan. Pada sebagian rumah di perumahan ini masih menggunakan pola tata ruang rumah tradisional Jawa berdasarkan komposisi ruang primer dan ruang servis, yaitu ruang servis yang berada di belakang ruang primer (Roesmanto, 2002). Hanya terdapat beberapa tambahan ruang seperti ruang makan, ruang setrika, ruang jemur, ruang belajar, garasi dan mushola. Hal ini sebagai cara beradaptasi manusia untuk menciptakan kepuasan setting lingkungan yang mampu mewadahi kebutuhan dalam hal keamanan, kreativitas, privasi dan ketenangan (Altman, 1992).

\section{Simpulan}

Place attachment merupakan terbentuknya ikatan batin seseorang terhadap suatu tempat, misalnya lingkungan hunian/rumah. Beberapa rumah di perumahan Candra Kiran Regency merupakan cerminan dari rumah masa kanak-kanak penghuninya karena hubungan mereka dengan keluarga di masa kecil. Hal ini terlihat dari hasil kajian terhadap pola tata ruang dalam yang terpengaruhi dari pola tata ruang rumah saat mereka kecil. Kesamaan tata ruangnya adalah hasil dari kenangan baik, sebaliknya kenangan negatif akan merubah tata ruang tergantung kepribadian yang terbentuk dari pengalaman-pengalaman dan latar budaya yang mempengaruhi perkembangan hidupnya. 


\section{Daftar Pustaka}

Asikin, D., Antariksa, Wulandari, L.D., \& Rukmi, W.I. (2017). Kearifan Lokal Migran Madura pada Permukiman Kotalama Malang. Seminar Nasional Arsitektur dan Tata Ruang (SAMARATA) Bali, ISBN 978-602-294-240-5.

Chawla, L. 1992. "Childhood Place Attachments" In Altman, I. and S. Low, ed. Place Attachment. New York. Plenum.

Gunawan, Undi. (2012). Deskripsi Arsitektur; sebuah metode fenomenologis pengalaman ruang dan bentuk arsitektur. Bandung. Disertasi program Doctor Arsitektur Universitas Katolik Parahyangan.

Groat, L.N. \& Wang, D. (2013). Architectural Research Methods. Second Edition. Wiley.

Mazianaomi, Yolanda, Sanjaya, Tisna. (2012). Berangkat dari Anak-Anak. Jurnal Tingkat Sarjana Seni Rupa No.1. ITB.

Mukhlis, Akhmad. 2016. Attacment Place : Studi Fenomena Special Place Anak Usia Dini di PAUD Islam TK Islam di Kabupaten Malang. Jurnal Pendidikan Agama Islam, Volume 4 No. 1 Mei 2016. ISSN (p) 2089-1946 \& ISSN (e) 2527-4511. Hal 135-156.

Rapoport, A. (1969). House Form and Culture. Prentice-Hall, Inc.

Roesmanto, Totok. (2002). A Study of Traditional House of Northern Central Java, A Case Study of Demak and Jepara. Journal of Asian Architecture and Building Engineering. November 2002/226.

Setyabudi, I., Antariksa, Nugroho, A.M. (2012). Tipologi Dan Morfologi Arsitektur Rumah Jengki Di Kota Malang Dan Lawang. Arsitektur e-Journal, Volume 5.

Stevanus, D., Thahir, A., \& Indartoyo. (2015). Studi Perubahan Fungsi Ruang Pada Unit Rumah Tinggal Di Cluster Orlando Dan Georgia, Kota Wisata Cibubur. AGORA, Jurnal Arsitektur, Volume 15, Nomor 1.

Sumoharjo, H. (2010). Analisis Data Kualitatif dalam Penelitian teknik Arsitektur. Inersia Vol. VI No. 1. 